\title{
From Walrasian General Equilibrium to Incomplete Contracts: Making Sense of Institutions
}

Mehrdad Vahabi

\section{(2) OpenEdition \\ Journals}

Electronic version

URL: http://journals.openedition.org/ei/709

DOI: $10.4000 /$ ei. 709

ISSN: 2553-1891

Publisher

Association Économie et Institutions

\section{Printed version}

Date of publication: 1 December 2002

Number of pages: 99-143

ISSN: 1775-2329

\section{Electronic reference}

Mehrdad Vahabi, « From Walrasian General Equilibrium to Incomplete Contracts: Making Sense of Institutions », Économie et institutions [Online], 1 | 2002, Online since 31 January 2013, connection on 19 April 2019. URL : http://journals.openedition.org/ei/709 ; DOI : 10.4000/ei.709 


\title{
From Walrasian General Equilibrium to Incomplete Contracts : Making Sense of Institutions
}

\author{
Mehrdad VAHABI ${ }^{1}$
}

\section{Introduction}

Walras' general equilibrium theory is an acontractual and ainstitutional theory. The impersonal character of market, based upon the participation of an infinite number of rational and profitmaximizing agents coordinated by a commissaire-priseur ${ }^{2}$, excludes bilateral contractual relationships. This theory is built upon two fictitious institutions : 1) the commissaire-priseur; 2) the compensation chamber. The first institution is devised to avoid bilateral contracts and to organize the "tâtonnement" procedure. The commissaire-priseur contributes to the formation of common knowledge with regard to prices, and guarantees the symmetrical information structure among dispersed agents. The second institution is devised to avoid monetary transactions, since a compensation chamber enables transactions without using money as a means of exchange. Hence, these two fictitious institutions have been provided for neglecting real institutions such as regulations regarding contractual relationships and money.

Arrow-Debreu's general equlibrium theory implicitly assumes certain institutions. For instance, the equal initial endowments of agents presupposes the existence of a certain kind of institution similar to a welfare state that guarantees this equal access to resources. Nonetheless, in the theoretical framework of Walrasian general equilibrium, institutions ${ }^{3}$ are either fictitious or given exogenously.

1 The author is Associate Professor at the University of Paris VIII, Département d'économie et gestion, 2, rue de la Liberté, 93200 Saint-Denis, France. Comments from participants in the Annual Conference of European Association for Evolutionary Political Economy (Pragues, 1999), as well as from Christophe Defeuilley, Oliver Hart, Sylvie Lupton and two anonymous referees are gratefully acknowledged. All remaining errors are the author's. The author would like to thank Mandana Vahabi without whose usual assistance this paper could not be prepared in the present form.

${ }^{2}$ Commisssaire-priseur is not a correct translation of Walrasian "crieur de prix" who is not an auctioneer but the one who only assumes the role of market secretary.

3 The purpose of this paper is not to provide a clear-cut definition for "institutions". Thus we will not treat this subject in detail. Borrowing Davis and North's distinction between "the institutional environment" and "the institutional arrangement", we contend : "The institutional environment is the set of fundamental political, social 
In an economy with diverse information, the Walrasian equilibrium does not lead to allocations that are as if each trader had all of the economy's information (Green, 1973) ${ }^{4}$. In the long run markets will not clear at the Walrasian equilibrium prices because agents observing those prices will extract information and thus revise their demands. The logical conclusion of this recontracting, i.e., the price vector at which no one desires to recontract, is the rational expectations equilibrium price vector. As Grossman (1989, chapter 2) shows in an economy where traders begin with diverse information but have rational expectations, the allocations are as if they were generated by a Walrasian equilibrium for an artificial economy where each trader has all of the economy's information. In other words, rational expectations price is in a formal sense, a sufficient statistic for all of the economy's information. By extending Arrow-Debreu's model to the case of asymmetrical information among agents, rational expectations hypothesis allows the treatment of contractual relationships. In fact the asymmetry of information poses the problem of coordination between individual plans and expectations. A contractual setup can provide an efficient solution to the coordination problem among individual agents with asymmetrical information if all contingencies can be accounted for in a rational way (for the adverse selection case and private disclosure see Grossman, 1977, 1989; Grossman and Hart, 1980)5. This explains why modern contract theory models assume rational expectations. Nevertheless, the underlying theoretical framework is partial and not

and legal ground rules that establishes the basis for production, exchange and distribution. Rules governing elections, property rights and the right of contracts are examples (..) An institutional arrangement is an arrangement between economic units that governs the ways in which these units can cooperate and/or compete. It (..) provides a structure within which its members can cooperate .. or provides a mechanism that can effect a change in laws or property rights" (Davis and North , 1971, p.p. 6-7). As O. Williamson underlines, the property rights literature deals with the institutional environment and hence investigates "formal rules (constitutions, laws, property rights)", whereas the transaction costs theory is concerned with the institutional arrangement (Williamson, 2000, pp. 598-99). In this paper, "institutions" refer to property rights. In studying property rights (as "rules of the game"), we particularly explore the relationships between these rights and institutional arrangements through the vertical/lateral integration problem. We may add to this formal institution of property rights, the informal institutions such as customs and traditions.

4 Green (1973) uses the rational expectations equilibrium concept in the context of traders with heterogenous information. In Green's model there is a class of traders (called informed traders) who have some information, say, $\alpha$, about the future value of the commodity. Another group of traders (called uninformed) do not know $\alpha$. There may be other temporary factors denoted by $\beta$ affecting the current spot price of the commodity. Hence the current price is some function $p(\alpha, \beta)$. As in Lucas (1972), uninformed traders observe the current price $\mathrm{p}$ and try to learn something about $\alpha$.

5 The results of signalling arguments as explored by Spence (1977) are somehow different in case of warranties and private disclosure about product quality (see Grossman, 1989, chapter 8). 
general equilibrium. A general equilibrium with rational expectations leads to a situation where recontracting is not desired by anyone, whereas in a partial equilibrium framework, rational expectations hypothesis provides an optimal incentive structure for conducting bilateral contract relationships.

The introduction of asymmetrical information structure between rational and maximizing agents is the sine qua non condition to make sense of bilateral contractual relationships. The Optimal Contracts Theory explores different incentive designs to reveal the private information among agents and examines the coordination problem in bilateral relationships between Principal and Agent. Nevertheless, the Optimal Contracts Theory cannot capture the "institutional identity" 6 of agents. In this paper, institutions are defined as "rules of the game" (property), although the play of the game (contract) is also required in order to take cognizance of institutional arrangements. Institutional identity is then grasped as the way property rights are distributed. In case of vertical integration, it means that an institutional theory should take on board whether A buys B or B buys A, and it matters which way this is done. Optimal Contracts Theory sidesteps either institutions as rules of the game or institutional identity ${ }^{7}$.

Since the second half of eighties, a new wave of studies on incomplete contracts has been undertaken under the influence of Transaction Costs Economics (T.C.E). This new literature which is most notably developed by the Property Rights approach (Hart, 1995) has largely contributed to understanding of the institutional identity of agents. In our viewpoint, this approach is very close to the T.C.E. and as Williamson (1996) contends it may even be regarded as a "fully formalized version of T.C.E". Nevertheless, one of the major differences of the Property Rights approach and T.C.E. resides in the fact that the former one tries to treat incomplete contracts on the basis of rationality postulate. This has caused a tension between the

6 The "institutional identity" is coined by Hart (1995) in order to underline the relevance of property rights. The fact that the property rights may influence the investment decisions brings us to acknowledge that it matters who owns the property. Here the property rights refer to the right to exclude others, and this right is different from the "monitoring" or "discretionary" power of Principal with regard to Agents. It should be noted that while the Coase theorem (1960) applies in case of complete optimal contracts, it does not apply in the presence of property rights.

7 One of the referees suggests that "a lot of interesting institutions can be explained using asymmetric information models, such as accounting conventions, product warranties, tournaments, and much else." If institutions can be defined in a broad way to include all kind of organizations, then this statement is true. However, the cost of adopting such a broad definition is that the institutional identity of agents becomes theoretically irrelevant. In other words, asymmetric information models cannot explain how the distribution of property rights can influence investment decisions. 
theoretical justification of incompleteness on the one hand, and rationality postulate, on the other hand. Two alternative solutions are formulated to overcome this tension. The first one is to deny the theoretical justification of incompleteness and to argue for complete optimal contracts as the sole appropriate theoretical framework for treating the contractual setting. This solution is explored by the Agency theory (Tirole, 1994). The other solution is to question the rationality postulate and to argue for the bounded rationality ${ }^{8}$ as the appropriate assumption to make sense of incompleteness (Williamson, 1996).

The purpose of this paper is to show that incompleteness and bounded rationality would be the sine qua non conditions to make sense of institutions. Contrary to what the partisans of complete optimal contracts advocate, we will argue that the asymmetrical information structure is not a necessary or a sufficient condition to found the institutions logically.

Section one examines the acontractual character of Walrasian general equilibrium. In section two, the theoretical relationships between complete and incomplete contracts are discussed. Finally, the third section investigates the tension between the rationality postulate and the contractual incompleteness. We conclude the relevance of bounded rationality assumption and temporary equilibrium framework to overcome some logical incoherences of present incomplete contracts literature. This brings closer two important branches of new institutional economics, namely the T.C.E. and the Property Rights approach.

\section{Walrasian General Equilibrium : An Acontractual Model}

Arrow and Debreu's general equilibrium model is acontractual, since thanks to the "crieur de prix", there is no bilateral contractual relationships among agents. In this model, the "recontracting" concept is used as synonymous to "tâtonnement" in order to denote

\footnotetext{
8 It should be noted that Leibenstein was one of the first theorists who emphasized the importance of contractual incompleteness and its relation with the bounded rationality assumption. He invoked three reasons for X-inefficiency : “(a) contracts are incomplete, (b) the production function is not completely specified or known, and (c) not all inputs are marketed or, if marketed, are not available on equal terms to all buyers" (1966, p. 412). Incomplete contracts were quite consistent with bounded rationality hypothesis. However, during sixties and seventies the mainstream economics regarded incomplete contracts as antinomical to the rationality axiom. This explains why incomplete contracts were ignored during this period by the mainstream economics (see De Alessi, 1983), whereas contractual setup was adopted in treating asymmetrical information.
} 
a simplifying assumption that no actual transactions take place at disequilibrium when prices are changed according to the law of supply and demand (Arrow and Hahn, 1971, pp. 264, 282). As Negishi (1972, 1989) and Walker (1973) justly underline this usage is, historically speaking, somewhat confusing. Since "recontracting" is originally due to Edgeworth (1881) who developed it in a direction different from that in which Walras (1874) developed his tâtonnement.

\subsection{Walrasian tâtonnement}

In Walrasian tâtonnement, disequilibrium transactions are excluded. In a decentralised economy with atomised agents, all traders are price-takers (Arrow, 1959) and the formation of prices is left to the "invisible hand", i.e. to the implicit Walrasian "crieur" (auctioneer). In this case, the auctioneer cries market prices and private traders react by revealing their plans of demand and supply (sometimes called "notional" demand and supply) to the auctioneer. However they do not make any trade contract among themselves until the auctioneer declares that equilibrium is established. The tâtonnement procedure is constructed in a way that no deviation can occur between the notional or expected demand (supply) and effective or realised demand (supply). The Walrasian equilibrium, i.e., the equality of supply and demand on markets (Benassy, 1982, 1986) is a state of complete compatibility of individual plans or perfect foresight (Hayek, 1937, 1945, 1946).

Recontracting in Walrasian tâtonnement relies upon the Law of Indifference. This law which is imposed as an axiom in the original Walrasian as well as in modern Walrasian economic theories implies the existence of uniform market prices even in disequilibria. This axiom may be justified either through arbitrage activities or by the existence of the auctioneer, and enables individual traders to act as price-takers who have only to adjust their plans of supply and demand to the given prices. Such an axiom is not imposed in Edgeworth's recontracting model.

\subsection{Edgeworth's recontracting}

Edgeworth starts with a simple two-good two-individual model of exchange, where a trader $\mathrm{X}$ offers a good $\mathrm{x}$ to a trader $\mathrm{Y}$ in exchange for a good $y$. If we consider the so-called Edgeworth Box 
diagram, any point on the contract curve, where each of two individual traders is not worse off than before exchange, can be a final settlement of trade contract which cannot be varied by recontract. To narrow down the range of possible final settlements Edgeworth introduces a second $\mathrm{X}$ and a second $\mathrm{Y}$, each respectively identical to the first, both in tastes and initial endowments. In this way Edgeworth shows that the range of possible final settlements shrinks as the number of identical traders grows. If there are infinitely many traders the only remaining final settlements turn out to be precisely the points of Walrasian equilibrium, each with a uniform price line, that is the common tangent to indifference curves of $\mathrm{X}$ and $\mathrm{Y}$ passing through the point of initial endowments. In the terminology of the modern theory of cooperative games, the core of the exchange game (i.e. those allocations not blocked by any coalitions of players) consists only of the Walrasian equilibria when the numbers of the Xs and the Ys are each infinitely large. As Negishi correctly states : "Though there are no uniform market prices and individual traders are not assumed to be price-takers in Edgeworth's recontracting process, the resulting equilibrium exchanges are the same as those obtained through Walrasian tâtonnement in a large economy. In such an economy, therefore, where information is perfect, we can safely argue as if there were uniform market prices and as if traders were price-takers." (Negishi, 1989, p. 293) ${ }^{9}$. In Edgeworth's recontracting process, traders take advantage of a free flow of information through the making and breaking of provisional contracts. This leads to the same uniform prices that are given by the auctioneer to price-taking traders in Walrasian equilibria. In other words, the acontractual character of Walrasian tâtonnement can be justified if the transmission of information is perfect and the speed of adjustment is rapid. This implies highly organised markets where every trader can easily find her partner and make transactions without any costs and without any recourse to tribunal to enforce them.

\footnotetext{
9 In a recent contribution, Nicolas Chaigneau (1997) suggests an alternative interpretation of Edgeworth's recontracting procedure. According to him, Edgeworth's theory should not be reduced to a limit case of Walrasian competitive equilibrium where the number of agents is infinite. Edgeworth's analytical rupture with the theory of supply and demand with given prices and his original analysis of imperfect competition have been particularly emphasized by the author. The advantage of this interpretation is that it allows us to provide a strong historical background for the modern theory of contractual market setting in the work of Edgeworth.
} 


\subsection{Arrow-Debreu's model and its limits}

The Walrasian equilibrium is "instantaneous" (Donzelli, 1989) and not dynamic. Moreover, it is deprived of uncertainty since the traders' plans of action are all compatible and these compatible plans are all carried out. However agents' plans of action may not be carried out partly due to the randomness in the physical world which is transmitted through the economic fundamentals (such as endowments, technology and preferences). This kind of randomness related to the objective probability of occurrence of a particular state of nature is dubbed as intrinsic uncertainty by the modern theorists of sunspot equilibrium (Cass and Shell, 1983, p. 194). Even if the fundamental parameters were non-random, economic outcomes would generally be random. This is because the economy is a social system composed of individual economic actors who are uncertain about each other's behaviour. Uncertainty of this sort is referred to as market uncertainty (Shell, 1989, p. 274). This uncertainty is related to the coordinating of the plans of the individual market participants and is not transmitted through the fundamentals. It is, therefore, an instance of extrinsic uncertainty. Arrow (1953) and Debreu (1959) incorporate intrinsic uncertainty into a Walrasian model of competitive equilibrium. They base their treatment of time and uncertainty on a specific institutional setup, that was called a futures economy by Hicks (1939). They assume that markets for exchanging commodities are opened at a single date, say date $t=0$. They assume further that at that date, markets exist for contracts to deliver commodities at each and every future date $t \geq 0$. The specification of a "commodity" will then involve not only the physical characteristics of the good or service to be delivered, but also the location and the circumstances ("state of nature") of the delivery. One gets then what has been called a "complete" set of futures markets at the initial date $t=0$ (Debreu, 1959, ch. 7).

It is clear that this framework is essentially timeless (Grandmont, 1987). Once an equilibrium is reached at date 0 (this equilibrium may be Walrasian or the result of any other game theoretic equilibrium notion), production and trade do take place sequentially in calendar time. But the coordination of the decisions of all traders is achieved at a single date through futures markets. There is no sequence of markets over time, and no role for expectations, money, financial assets, or stock markets. The ArrowDebreu model requires in principle a complete system of insurance and futures markets covering all market contingencies, which appears to be too complex, detailed, and refined to have practical significance. A further obstacle to the achievement of a complete 
insurance market is the phenomenon of "moral hazard" (Arrow, 1965). Moreover, once we recognize explicitly that there is a sequence of markets, one for each date, and not one of them complete (in the Arrow-Debreu sense), then certain phenomena and institutions not accounted for in the Arrow-Debreu model become reasonable. First, there is uncertainty about the prices (extrinsic uncertainty) that will hold in spot markets for future dates, as well as uncertainty about the environment (intrinsic uncertainty) (Radner, 1980). Second, producers would not have a clear-cut natural way of comparing net revenues at different dates and states. Stockholders have an incentive to establish a stock exchange since it enables them to change the way their future revenues depend on the states of environment. As an alternative to selling her shares in a particular enterprise, a stockholder may try to influence the management of the enterprise in order to make the production plan conform better to her own subjective probabilities and attitude towards risk. The relationship between principal (stockholders) and agent (manager) and the internal institutional arrangement of enterprise (corporate governance) become crucial once asymmetric information or different subjective probabilities between agents are taken into account (Jensen and Meckling, 1976; Jensen, 1986; Williamson, 1988). Third, consumers will be subject to a sequence of budget constraints, one for each date rather than to a single budget constraint. For consumers will typically not be able to discount all of their "wealth" at the beginning of time due to the uncertainty associated to their shares of producers' future net revenues. Fourth, agents will be interested in forecasting the prices in markets at future dates. In deciding their plans, individual agents have to form anticipations about future prices. Nothing guarantees that these anticipations are correct, so that individual plans will be revised with the passage of time. Fifth, if traders have different information at a particular date, then the equilibrium prices at that date will reflect the pooled information of the traders, albeit in a possibly complicated way. Hence traders who have a good model of the market process will be able to infer something about other traders' information from the market prices.

\subsection{Extended model of general equilibrium and bounded rationality}

In a sequential vision of the market process changing in real calendar time, no market at any one date is complete in the ArrowDebreu sense. In such a universe, the asymmetry of information between agents and the way they form their expectations determine 
whether the sequence of temporary equilibria at each unitary period of time coincides with the equilibrium over the whole period of time which can be defined from the hypothesis of a full system of markets (Hahn, 1968). Among different possibilities, two alternative solutions are particularly noteworthy. The first one is to adopt a rational expectations hypothesis which allows the general equilibrium model to be extended to cover the case in which different traders have diverse information. An example of the rational expectations approach is the theory of intertemporal equilibrium. The second approach which is much less well defined is known as bounded rationality. It assumes that the trader's planning horizons are severly limited, or that their expectation formation follows some simple rules-of-thumb. An example of the bounded rationality approach is the theory of temporary equilibrium (see Grandmont, 1987).

In a rational expectation equilibrium (Lucas, 1972, 1980), not only are prices determined so as to equate supply and demand, but individual economic agents correctly perceive the true relationship between the non-price information received by the market participants and the resulting equilibrium market prices. The rational expectations model is capable of capturing the idea that prices inform individuals as well as allocate resources. It has been used to formalize the idea that if markets are complete, but information is dispersed throughout the economy, then there exists a rational expectations equilibrium that yields allocations that could not be Pareto dominated by a central planner in possession of all the economy's information (Grossman, 1981). This is a much stronger theorem than the fundamental theorem of welfare economics for Walrasian equilibrium. The standard optimality result essentially says that in an economy where markets are complete and all consumers have identical information, then a planner with the same information cannot Pareto dominate the competitive allocations (Hurwicz, 1973). Grossman's theorem states that in an economy where traders may have arbitrarily diverse information, the allocations brought about by competitive prices are as if each trader had all the information. Hence these allocations cannot be Pareto dominated. Borrowing Shackle's distinction between the ex ante vision of economic actor (producer or businessman) and the ex post vision of the economic analyst, the rational expectations hypothesis can be interpreted as if an economic actor infer from the price system the true model of economic system as regarded by the economic analyst (Vahabi, 1998). In this perspective the ArrowDebreu's contingent equilibrium can be defined in a slightly different way. A rational expectations equilibrium considers the contingent equilibrium as a succession of equilibria over present markets in 
which current prices are fixed in accordance with the individual economic actor's expectations of the price evolution on the basis of a true model of the market process (Lucas, 1980, p. 707). A proper definition of an equilibrium price $\mathbf{P}^{\mathbf{0}}(\mathbf{y})$ is one where there is no desire to recontract when each trader gets what he demands at $\mathbf{P}=\mathbf{P}^{\mathbf{0}}(\mathbf{y})$ after he is informed that the market-clearing price is $\mathbf{P o}(\mathbf{y})$. Now in an economy knowing random shocks, let $\mathbf{s}$ be a random variable that takes on $\mathrm{n}$ values $\mathbf{s}_{1}, \mathbf{s}_{2}, \ldots, \mathbf{s}_{\mathbf{n}}$ and that each trader $\mathbf{h}$ has information $\mathbf{y}^{\mathbf{h}}$ about $\mathbf{s}$. In such economy at what price $\mathbf{P} \mathbf{0}(\mathbf{y})$ will there be no desire to recontract after traders observe that $\mathbf{P}=\mathbf{P} \mathbf{0}(\mathbf{y})$ ? This price must have the property that the allocation that each trader $\mathbf{h}$ gets is what he demands, when his demand is formed by conditioning on $\mathbf{y}^{\mathbf{h}}$ and $\mathbf{P}^{\mathbf{o}}(\mathbf{y})$. This is precisely the property that Lucas (1972) requires of rational expectations under asymmetric information ${ }^{10}$. Accordingly, markets are always in equilibrium and an intertemporal equilibrium is always realised as a succession of temporal equilibrium. This approach generalizes the neoclassical framework.

An alternative approach dubbed as bounded rationality contends that in the evolution of a sequence of monetary equilibria, each agent's expectations will be successively revised in the light of new information about the environment and about current prices. Therefore, the evolution of the economy will depend upon the rules or processes of expectation formation and revision used by the agents. This evolution of sequential equilibria would not necessarily converge to the long term equilibrium, since agent's expectations cannot be fully rational and the market process is marked by incompleteness and disequilibria. In this approach markets are never complete, because all market contingencies can never be known in advance and sheer ignorance overrules the attachment of any probability to their occurrence. Following this different line of attack, Herbert Simon (1959, 1962), and others generally associated with the Carnegie School rejected maximizing behavior and focused on the process of decision making within the firm. Key notions of this approach included saticfycing, multiple goals, organisational slack, resistance to change, and other "behavioral" characteristics (Day, 1965).

\footnotetext{
10 See Shiller (1978), Barro (1981), Guesnerie and Woodford (1991), Azariadis (1993) for a survey of macroeconomics and rational expectations, and Radner (1980), Spear (1985), Evans and Honkapohja (1992) for a survey of the microeconomics and mathematical theory of rational expectations.
} 


\section{Comprehensive and Incomplete Contracts: A World with Two or Three Parties}

Equilibrium in a neoclassical world satisfies all the Paretoefficiency conditions under both competitive and monopolistic market structures. Additional characteristics of neoclassical theory deserves emphasis. In particular, 1) transaction costs are zero: broadly interpreted, this means that the costs of obtaining information about alternatives and of negotiating, policing, and enforcing contracts are zero (Dahlman, 1979); 2) adjustment costs are zero; 3) all resources are fully allocated and privately held; 4) owners allocate resources to productive purposes purely in response to pecuniary incentives; and 5) the entrepreneur's choice between income and leisure is independent of income (Tibor Scitovsky, 1943). Although in Arrow-Debreu's model the atomised agents are infinite, they all possess the same information and the same motivational structure and there is no personal ties among them. The acontractual character of the model stems directly from the fact that it is built upon the hypothesis of symmetrical information among agents. The pitfalls of this model are undeniable: it ignores incentive problem and internal organisation of firm. Furthermore, the boundaries of the firm and the difference between various organisational and institutional arrangements are not explained. The introduction of imperfect competition is one way to overcome these shortcomings. An alternative way is to study in more detail the process of contracting, particulary its hazards and imperfections. In doing so, the agency theory starts from the hypothesis of asymmetrical information structure between agents and principals. Principal-Agent theory ${ }^{11}$ recognizes conflicts of interest between different economic actors, formalizing these conflicts through the inclusion of observability problems and asymmetries of information. Although the theory defines firm as a "nexus of treaties", it shares with the standard neoclassical theory the idea that the firm may be described as a production function. However it contends that a professional manager makes production choices, such as investment or effort allocations, that the firm's owners do not observe. Because the manager deals with the day-to-day operations of the firm, she also is presumed to have information about the firm's profitability that the owners lack (Hart, 1989). In this way, the agency theory provides a theoretical framework for the analysis of a world with two different agents or two parties of a contract, namely Principal and Agent.

${ }^{11}$ For surveys, see Rosen (1985); Hart and Holmstrom (1987) and Sappington (1991). 


\subsection{Asymmetrical information and comprehensive}

contracts

Underlying each agency model is an incentive problem caused by some form of asymmetric information ${ }^{12}$. It is common to distinguish models based on the particular information asymmetry involved. All models in which the agent has precontractual information can be dubbed as adverse selection. However certain models assume that agents have symmetrical information at the time of contracting. Within models of this category, which we refer to as moral hazard, a further distinction is useful: the case where the agent takes unobservable actions, and the case where his actions (but not the contingencies under which they were taken) may be observed (Hart and Holmstrom, 1987). Arrow (1985) has suggested the informative names "Hidden Action Model" and "Hidden Information Model" for these two subcategories. The worker supplying unobservable effort is the typical hidden action case, while the expert manager making observable investment decisions leads to a typical hidden information model.

The analytical core of contract theory in general and agency theory in particular is an optimization problem, whereas in imperfect competition it is an equilibrium problem. However most contracting analyses are also partial equilibrium. Most contract theories are based on the assumption that the parties at some initial date (say, zero) design a Pareto optimal long-term contract. Optimality is not to be understood in a first best sense, but rather in a constrained or second best sense. Indeed, information and other restrictions that force the contract to be second best are at the heart of the analysis. In fact, without them one would quickly be back to the standard Arrow-Debreu paradigm where contractual form is inessential. As Hart rightly notes "although the optimal contract in a standard principal-agent model will not be first best (since it cannot be conditioned directly on variables like effort that are observed by only one party), it will be 'comprehensive' in the sense that it will specify all parties' obligations in all future states of the world, to the fullest extent possible. As a result, there will never be a need for the parties to revise or renegotiate the contract as the future unfolds. The reason is that, if the parties ever changed or added a contract clause, this change or condition could have been anticipated and built into the original contract." (1995, pp. 21-22). The term 'comprehensive' is

12 Although team theory (Marshak and Radner, 1972) also deals with the asymmetrical information, agents are supposed to be utopian in their interest orientation. Completely rational and opportunistic individuals populate the models of moral hazard, incentives, adverse selection and market signalling. 
used here in a judicial sense and not in an economic one. In this context, a complete contract is one that specifies each party's obligations in every conceivable eventuality, rather than a contract that is fully contingent in the Arrow-Debreu sense. According to this terminology, the asymmetric information in a standard principalagent model should be regarded as a 'comprehensive' or a complete contract. One would also not expect to see any legal disputes in a comprehensive contracting world. The reason is that, since a comprehensive contract specifies everybody's obligations in every eventuality, an outsider (for instance, a court) could costlessly determine whether one of the parties has been in breach of contract and impose an appropriate penalty. As a matter of fact, as Dewatripont (1989) justly underlines, not only does renegotiation not add anything in the standard principal-agent model, but the possibility of it can actually worsen matters! In such a world, it is hard to see what the benefits or costs of integration could be. The general point is that with zero transaction costs, any rights that ownership may confer can be undone through a contract. Hence an optimal outcome can be achieved whether A and B are separate firms or part of the same firm. In other words, ownership is simply irrelevant.

It is noteworthy that the argument that ownership is irrelevant under comprehensive contracting is robust to the introduction of asymmetrical information, for instance, in the form of moral hazard or adverse selection. Asymmetric information leads to departures from Arrow-Debreu "contingent contracting"13, but it does not provide a role for ownership unless the limits to contracting are themselves sensitive to who owns what. In particular, under asymmetric information optimal contracts will still be "complete"; and hence it will be possible for any rights that ownership confers again to be contracted away. For example, if a seller (S) of an input has private information about his costs, then an optimal contract between (S) and a buyer (B) will make the quantity of input to be traded and the price to be paid a function of S's announced costs. In order to encourage truth-telling by (S), the contract will typically involve some production inefficiency, i.e., it will be second best. However, the point is that this production inefficiency, will be present whether (S) and (B) are separate firms or are integrated; it is a function of the asymmetry of information, not of who owns what.

13 The expression "contingent contracting" in Arrow-Debreu's sense does not refer to a bilateral contract; it only describes buying and selling of commodities according to different market contingencies. In this sense "contract" describes any transaction, while in contractual literature the term is reserved for "formal, legal commitments to which each party gives express approval and to which a particular body of law applies" (Scott Masten, 1998, p. 1). Thus the utilisation of this expression is not contradictory with the idea that Arrow-Debreu's model is acontractual. 
The only exception to this is if the asymmetry of information itself depends on the ownership structure; that is, a change in ownership affects what contingencies can be included in the contract and what cannot. Asymmetrical information is, hence, a necessary condition in order to pass from Arrow-Debreu's acontractual model to optimal contractual models. However, it is not sufficient to make sense of the institutional identity of agents. This condition brings us from an acontractual world of many agents to a contractual world of two agents. However in a complete contracting procedure there is no special need for any third party (for example, a court) to enforce the contract ${ }^{14}$. Thence it cannot be a world of three agents.

\subsection{Incomplete contracts and institutional identity}

We defined above Arrow-Debreu's market setting as a world of infinite agents. In fact, it must be emphasized that their market setting may also be characterized as impersonal where people make trades "with the market". Moving away from this impersonal acontractual market setting to a situation where firm A and firm B, or firm $\mathrm{C}$ and union $\mathrm{D}$ write a long term contract has a great economic significance. In his theory of "fundamental transformation", Oliver Willimson (1985), in particular has stressed the importance of situations where a small number of parties make investments which are to some extent relationship-specific, that is, investments ${ }^{15}$ that enhance the value of trade but that are of substantially less value outside the relationship ${ }^{16}$. Given this "lock in" effect, each party will have some monopoly power ex post, although there may be plenty of competition ex ante before investments are sunk. Since the parties

\footnotetext{
14 We are not suggesting that a Principal-Agent (PA) model cannot be multilateral, comprised of many principals or many agents. We are only stressing two distinctive features of such models. First, a PA model is based on a bilateral contractual relationship and not on an impersonal one. Such models adopt a partial and not a general equilibrium framework. Second, a PA model does not need any noncontracting party (a third party such as court) to implement the contract.

15 The word "investment" should be interpreted broadly; the same factors will apply whenever one party is forced to pass up an opportunity as a relationship with another party (for example, A's "investment" in the relationship with B may be not to lock into C). Thence the crucial element is a sunk cost (direct or opportunity) of some sort. An effort decision is one example of a sunk cost.

16 Relationship-specific investments take many forms, including human, organisational, and physical capital. Classic examples are the specialised dies used by Fisher Body to stamp out auto bodies for GM cars (Benjamin Klein et al., 1978), and the "check-by-jowl" or "mine-mouth" locations of electrical power plants near coal mines (Paul Joskow, 1985). See also Goldberg and Erickson (1982)'s study of petroleum coke.
} 
cannot rely on the market once their relationship is specific, the alternative way to organise trade is through a long term contract.

However, writing a long term contract is not so obvious, since it bears many costs known as "transaction costs". Moreover, a relationship specific investment generates a particular problem which Williamson $(1975,1985)$ dubbed as "holdup problem". The holdup literature postulates that parties cannot sign "complete" contracts which specify efficient trade for each possible state of the world. Yet, investments must be sunk before the state uncertainty is resolved, and so in subsequent negotiations a party will lose part of the returns to his or her relationship-specific investment. This literature consequently suggests that incomplete contracts lead to underinvestment in specific assets ${ }^{17}$. This result is contested by the literature on legal remedies for breach of contract which predicts the reverse (Shavell, 1980; and Rogerson, 1984; for a general survey, see Malcomson, 1997). Comparing two familiar breach remedies, namely expectation damages and specific performance, Aaron Edlin and Stefan Reichelstein (1996) integrates the intuition of the legal remedies literature with that of the holdup literature. They show that noncontingent fixed price contracts can often provide efficient investment incentives by balancing "holdup contingencies" where an investment is undercompensated against "breach contingencies" where it is overcompensated. "The overinvestment problem that Rogerson and Shavell identify is not an essential feature of legal remedies, but stems from the particular contracting options they consider." (Edlin and Reichelstein, 1996, p. 479).

Rogerson (1992) shows that first best contractual solutions to the holdup problem exist if certain environmental properties are satisfied and if "powerful" contracts can be written. According to him, three environmental properties must be satisfied: "1) Risk neutrality. 2) No externalties. Each agent's investment directly affects only his own type...3) Only one investor under partially private information (PPI). If the PPI case holds, then only one agent makes an investment decision." Furthermore, the contrasts are "powerful" in three senses: "1) Complexity. Complex contracts can be written. 2) Commitment to participate. Agents cannot simply decide to renege on the contract if it turns out that they expect to make losses at some point. 3) No renegotiation. The contract can prevent agents from attempting to renegotiate the outcomes of the contract." (Rogerson, 1992, p. 788). In this context, the holdup problem does not cause inefficiencies if

17 For discussions of the holdup problem, see Williamson (1985); Klein et al. (1978); Grossman and Hart (1986) and Hart and Moore (1988). For formalisations see Grout (1984) and Tirole (1986). 
certain strong hypotheses, such as no renegotiation and the possibility of writing complex contracts hold.

Introducing transaction costs and bounded rationality, Williamson underlined not only the holdup problem in presence of specific investment and the inefficiencies stemming from it, but he also inferred the "incomplete" character of contracts in such cases. Again in using the term "incomplete", we must be cautious not to confuse its judicial connotation with its economic sense. As Ayers and Gertner (1992) contend, to a lawyer, "incomplete" means that the obligations of the parties are not clearly specified. However, economists (for example, Hart and Moore, 1988) understand by that term a type of contract that cannot be conditioned on all the events that affect the payoffs to the parties ${ }^{18}$. In this sense, a contract is incomplete or "silent" when it contains gaps or missing provisions: the contract specifies some actions the parties must take but not others; it mentions what should happen in some states of the world, but not in others.

Contractual incompleteness in the property rights literature is essentially related to the "unverifiability" condition and should not be confused either with incompleteness in general, or incompleteness in a judicial sense. For example, consider a specific performance contract which specifies that agent $A$ should provide agent $B$ with a particular product, but which does not precise the damages in case if the terms of contract have not been respected. Such kind of incompleteness is very common in real life and can be attributed to the "bounded rationality" of agents. However, the property rights literature does not study this kind of incompleteness. It assumes that the parties are constrained in contracting "only by the fact that complicated states of nature cannot be verified." (Hart and Moore, 1999 , p. 134). For instance, consider a contract which indicates that agent $\mathrm{A}$ must provide agent $\mathrm{B}$ with $\mathrm{X}$ quantity of a certain product at a fixed price and if the performance turns out to be impossible, agent A should pay a large amount of damages. Such a contract is incomplete if the parties would really have liked to make the number of products contingent on the state of nature. It is in this particular sense that the property rights literature interprets the contractual incompleteness. Ayers and Gertner (1992) refer to such contracts as "insufficiently state contingent". It is noteworthy that in such kind of contracts, the parties' obligations are fully specified in all circumstances and there is no incompleteness in the judicial sense. Nevertheless, there exists a contractual incompleteness in the sense that "the parties would like to add contingent clauses, but are

18 Tirole (1994), Maskin and Tirole (1999), Segal (1999), Macleod (1996), and Hart and Moore (1999) discuss the foundations for incomplete contracts in more depth. 
prevented from doing so by the fact that the state of nature cannot be verified." (Hart and Moore, 1999, p. 134).

In the legal literature on contracts, every contractual dispute that comes before the court concerns a matter of incompleteness. In fact, incompleteness is probably at least as important empirically as asymmetric information as an explanation for departures from "ideal" Arrow-Debreu contingent contracts. Here a clear distinction between asymmetrical information and incompleteness is necessary. Although asymmetrical information is a necessary condition to pass from acontractual world to a comprehensive contractual world, it is not necessary to make sense of "incomplete" contracts ${ }^{19}$. In an incomplete contract both parties may recognize that the state of the world is such that the buyer's benefit is high or the seller's cost is low, or the quality of an item is good or bad or that an investment decision is appropriate or not. The difficulty is conveying this information to others.

To put it differently, while the parties to a contract may have symmetrical information, it is the asymmetry of information between the parties on the one hand, and outsiders (such as the courts) on the other hand, which is the root of the problem. To use the jargon, incompleteness arises "because states of the world, quality, and actions are observable (to the contractual parties) but not verifiable (to outsiders)." (Hart and Holmstrom, 1987, p. 134). The incomplete contractual world involves at least three agents and the third party represents an institution such as court, custom, reputation, etc. The particular difficulties related to conveying information to a third party is especially stressed in the theory of tacit knowledge (Hayek, 1968; Polanyi, 1967, Nelson and Winter, 1982). As Bruce Caldwell justly observes modern theorists were quick to pick up on Hayek's insight that, in a world of dispersed knowledge, "prices convey information. The same cannot be said about his writings on localised and tacit knowledge" (Caldwell, 1997, pp. 1865-1866; see also Vahabi, 1995, 1997). The asymmetrical information is essential to comprehend the incentive problem of agents, while the tacit dimension of knowledge is crucial for understanding the institutional setup of spontaneous market order (or "Catallaxy"). In this sense, Hayekian theory of knowledge is closer to incomplete contracts than to comprehensive ones.

19 We argue later that the signalling effect in a world of asymmetrical information can also be invoked in order to cause incomplete contracts (for example, see Spier, 1992). However, an incomplete contract can be generated in the presence of symmetrical information. 
According to Hart and Holmstrom, the distinction between an incomplete contract and a standard asymmetric information contract resides in the fact that the former "allows reputation to operate, since the parties have the same information and can observe whether reasonable behavior is being maintained. In the latter case, it is unclear how reputation can overcome the asymmetry of information between the parties that is the reason for the departure from an Arrow-Debreu contract." (1987, p. 142). The importance of "reputation" as an incorporeal specific asset (non-human asset) is particularly stressed by Williamson (1985), Tirole (1988), Kreps (1990), and Hart (1995). The influence of reputation on organisational form and property structure has also been widely studied (see Garvey 1991, Halonen, 1994).

The reputation effect is more consistent with symmetrical information case in a repeated game and that fits well with an incomplete contractual setting. It is noteworthy that asymmetric information also plays a limited role in the analysis of the holdup problem. Particularly the analysis of renegotiation is much more tractable under the assumption of symmetrical information. From a purely economic point of view it is more natural to study the holdup problem in the context of symmetric information. The holdup problem is most acute when Agent 2 (A2) observes Agent 1 (A1)'s investment and can exploit A1's eagerness for the product to claim a high price. Although as Tirole (1986) remarks a holdup problem can also arise if A2 is unsure about whether A1 has invested, but it is less extreme.

The incompleteness of contracts opens the door to a theory of ownership. In particular, when contracts are incomplete, it is no longer the case that any rights conferred by ownership can necessarily be contracted away, since it may be impossible to describe these rights unambiguously. An incomplete contract will have gaps, missing provisions, or ambiguities, and so situations will occur in which some aspects of the utilisation of nonhuman assets are not specified. In such cases, ownership is a source of power. According to the property rights approach, it is the owner of an asset who has the residual control rights over the asset. It means the right to decide all usages of the asset in any way not inconsistent with a prior contract, custom, or law. To the extent that ownership of an asset guarantees residual rights of control over that asset, vertical and lateral integration can be seen as ways of ensuring efficient allocations of residual decision rights.

The property rights approach adopts the lawyer's definition of ownership as residual control rights or the "right to exclude" (Hart, 
1989 , p. 1765) 20 . This is in contrast to the more standard definition of ownership, whereby an owner possesses the residual income from an asset rather than its residual control rights ${ }^{21}$. As Hart (1995, p. 87) stresses there are two crucial ingredients of the property rights approach: "incomplete contracts, and residual rights of control over nonhuman assets." Given the non-contractibility of relationship specific investments, the first ingredient is important because it leads to a holdup problem. The second ingredient is important because it implies that changes in ownership could curb the holdup problem. The importance of holdup problem notwithstanding, asset ownership still matters even in the absence of such a problem.

According to the property rights approach "what is required for a theory of asset ownership is that there is some inefficiency in the economic relationship, which the allocation of residual rights can influence: the inefficiency could be an ex post one rather than an ex ante one." (Hart, 1995, p. 87). This approach emphasizes the distorsions, due to contractual incompleteness, that can prevent a party from getting the ex post return required to compensate for her ex ante investment. To the extent that the marginal and average values of investment move together, the allocation of ownership rights, by changing the average investment return, will affect the level of investment. Integration is optimal when one firm's investment decision is particularly important relative to the other firm's. Whereas non-integration is desirable when both decisions are somewhat important ${ }^{22}$. Furthermore, contractual incompleteness can lead to other distorsions. For instance, even if all ex ante investments can be verified and hence are repayable (implying the absence of sunk costs), residual rights may matter if the ex post distribution of

\footnotetext{
${ }^{20}$ Hart acknowledges that property rights include residual income and residual control rights. Nonetheless, he prefers to define property rights in terms of residual control rights. Although Hart's approach has been initially used in the theory of the firm, it has been also employed in the financial contracting. However, this latter literature focuses on how the allocation of control rights affects the trade-off between cash flows and private benefits once the relationship is underway (Hart, 2001). It should be noted that Hart borrows his definition of property rights from a well-known American lawyer, Oliver Wendell Holmes (1881) (see Hart, 1995, p. 30).

${ }^{21}$ In Boycko, Shleifer and Vishny (1996, p. 310), the privatisation is defined as the reallocation of control rights over employment from politicians to managers and the increase in cash flow ownership of managers and private sectors. This definition captures both aspects of property rights, namely the residual control rights and residual income which is treated separately by the standard and modern theory of property rights.

${ }_{22}$ It should be noted that the property rights theory applies the same concept of residual rights of control to explain the costs of integration as well as the benefits. Put differently, in contrast to most previous work (for example, the Williamsonian transaction costs theory), the disadvantages of integration are explained without resort to such notions as bureaucracy.
} 
the surplus is important for other reasons, for example, because of the risk aversion of the parties.

The contention that the distribution of ownership rights has efficiency consequences should be contrasted with the standard result in the property rights literature that in an externality-free world, private property is efficient. According to Coase theorem (1960) if transaction costs are zero, then the property rights will be fully defined, fully allocated, and fully enforced. Moreover, they will be reallocated to their highest-valued use regardless of their initial assignment. To put it differently, only if a property is privately owned, will a user get the full return from his activities and hence take socially efficient actions. In this literature, efficiency is achieved whoever owns the property, as long as the property rights is welldefined and not too widely dispersed. This last condition is necessary so that negotiation costs between different owners are avoided (Harold Demsetz, 1997).

It is worthwhile to consider which of the assumptions of the Coase theorem is revised by the modern property rights approach ? In Coase (1960) contracts are comprehensive and ex post bargaining is permitted among agents. However the ex ante efficiency of the relationship between the two parties will depend on how residual rights of control are allocated. As Grossman and Hart (1986, p. 718) contend: "The impossibility of ex ante bargaining over all aspects of the production to be delivered, that is, the incompleteness of the contract, is the source of our conclusion that the distribution of property rights has efficiency consequences." Although the "intellectual debt" of the modern property rights approach to the property rights literature (Alchian, Coase, Demsetz, Furuboton) is acknowledged by the former (see Hart, 1988, p. 127), the crucial difference between them must not be ignored.While Coasian paradigm makes sense in a comprehensive contractual setting and takes for granted the efficiency whoever owns the property, the modern approach argues in an incomplete contractual world and underlines the importance of agent's institutional identity to have efficiency.

\section{Incomplete Contracts and Bounded Rationality}

Incompleteness raises new questions about the behavior of the contracting parties. Since incomplete contracts contain many "gaps" and are "silent" on some of the parties' actions, additional explications are required to clarify how these gaps are filled in. In 
this context, outside influences such as customs or reputation may become important. Furthermore, outsiders such as the court may have a role to play in filling in missing provisions of the contract and resolving ambiguities. Incompleteness can also cast some light upon the importance of the allocation of decision rights or rights of control. As Aghion and Tirole (1995) argue, the incomplete contracting framework can be applied to the study of authority, since nobody can be "in charge of" an action or decision if all actions can be specified in a contract ${ }^{23}$. In brief, incompleteness opens the door to the analysis of institutions. But to what extent the introduction of institutions can be compatible with the rationality postulate? According to North, "There are no institutions (or if they exist they play no independent role) in the neoclassical world because the instrumental rationality postulate renders them superfluous." (1993, p. 15). This poses a very difficult question: How can the property rights approach capture incompleteness while maintaining the rationality postulate?

\subsection{Incompleteness: causes and consequences}

Since the Simon (1951), Williamson $(1975,1985)$, Klein et al. (1978) and, more recently 24 , the Grossman and Hart (1986), and Holmstrom and Tirole (1989) seminal contributions, a number of papers have discussed incomplete contracts. One branch of this literature assumes that contracts are incomplete and proceeds to analyze the consequences of incompleteness on the economy. This literature concentrates on the role of available mechanisms and institutions in mitigating the inefficiencies generated by contract incompleteness, such as vertical and lateral integration (Grossman and Hart, 1986) and the optimal allocation of ownership rights on physical capital (Hart and Moore, 1990). A second branch of this literature differs from these papers since it does not assume contract incompleteness but tries to derive it endogenously. To our knowledge, at least five types of models can be distinguished in this second branch.

\footnotetext{
23 Borrowing Weber's distinction between "real authority" and "formal or legal" authority, Aghion and Tirole (1995) argue that someone with superior information may have effective power, although he does not have legal power, since those with legal power (for example, owners) may follow his suggestions. Actually, owners (principals) may deliberately create an asymmetry of information, so that agents can wield power and can thereby be rewarded for making relationship-specific investments.

${ }^{24}$ As Hart and Moore (1988) justly remind Weitzman (1981) has also contributed to this literature.
} 
1) Non-verifiability by the third party: Hart and Moore (1988) and a number of subsequent papers (Cheung, 1991; Aghion, Dewatripont, and Rey, 1994; Nôldke and Schmidt, 1995, Bernheim and Whinston, 1998) ask the question of whether one of the causes of contract incompleteness is the fact that the outcome that the parties wish to implement through a contract may be, at least in part, unobservable by the third party or enforcing agency such as the court. They conclude that the parties will write a "silent" (incomplete) contract which will leave out some details that the court cannot observe. Whether the implemented outcome will differ from the socially efficient one, seems to be highly dependent on how much exactly the court observes of the contracted transaction. In this strand of models, the incompleteness is caused by a particular type of transaction costs.

Among transaction costs, two sorts of costs should be particularly highlighted: 1) The ex ante transaction costs of writing a contract; 2) the ex post transaction costs of enforcement. The first one takes on the board that even if the contractual parties can plan and negotiate about the future, it may be very difficult for them to write their plans in such a way that, in the case of a dispute, an outside authority (for example, a court) can figure out what these plans mean. In other words, the parties must be able to communicate not only with each other, but also with outsiders who may have little knowledge about the environment in which the contracting parties operate. Borrowing Hart's terminology (1990), we can say that this type of transaction costs is due to the bounded rationality of the judge or the third party in contrast to the bounded rationality of contractual parties. The second one, namely the cost of enforcement is impending whenever contracts are not self-enforcing. It is the most likely and indeed empirically observable state in which the parties have a great deal of knowledge about each other and are involved in repeated dealings. In such a world, the measured costs of transacting are very low because of a dense social network of interaction. However, enforcement is typically imperfect for two reasons. The first one relates to the costs of measuring the multiple margins that constitute contract performance. The second resides in the fact that enforcement is undertaken by agents whose own utility functions influence outcomes. The enforcement problem is particularly explored by the Measuring Branch of Transaction Costs economics or the University of Washington approach (see notably, Barzel, 1982, 1989; Hashimoto, 1981; North, 1981, 1984). The emphasis upon enforcement is one of the major differences between Williamson's approach to transaction costs and North's analysis (North, 1990, chapter 7) which tries to capture historical evolution. For, according to North, "The key problems of institutional change, of contracting, 
and of performance turn on the degree to which contracts can be enforced between parties at low cost.” (1990, p. 55).

2) Difficulties and costs of writing the contract: In Anderlini and Felli (1994), all the parties (enforcing agency included) can, in principle, observe all the relevant variables. They are constrained only by what they can write into the contract. They derive the incompleteness of contracts from the assumption that, to be enforceable, a contract must be formal. In turn, formality means that the mapping between states of the world and prescribed outcomes is 'general recursive', or equivalently, is computable by a Turing machine. Their definition of incomplete contracts is more general than the one usually proposed in the economic literature. They define incompleteness as a property of the 'partition' of the possible states of nature that the contract induces, since it is this partition which characterizes how much of the relevant information is included in the contract itself. In Dye (1985), the incompleteness is also endogenously derived from a complementary but different from Anderlini and Felli's paper. They consider the costs of specifying contingencies as the cause of incompleteness.

3) The asymmetrical information: Many authors (Hermalin, 1988; Aghion and Hermalin, 1990; Allen and Gale, 1992; Spier, 1992) try to explain the incompleteness by the signalling effect of the parties' willingness to include a contingency in the contract in a world of asymmetric information. Spier (1992) particularly explores the idea that strategic considerations during contract formation may lead to contractual incompleteness. It is shown in a stylized principal-agent model with transaction costs that there exists a range of parameter values for which the good type of principal signals that she is good through an incomplete contract, even though under full information she would have offered a complete contract. The intuition for this result is as follows: since the agent's pay off is assumed to be independent of the principal's type within the class of incomplete contracts, signalling concerns make complete contracts relatively more expensive for the good type of principal. Consequently, she is likely to forego completeness for the less expensive option. Another type of asymmetric information relates to the ambiguity in common information about the contingent events (Mukerji, 1998). The parties to a contract may have beliefs that are "captured not by a unique probability distribution in the standard Bayesian fashion but instead by a set of probabilities, any one of which could be the "true" distribution." (Mukerji, 1998, p. 1208). If the agents would be ambiguity averse, they may be led to establish an incomplete contract. 
As argued in section two, asymmetric information is not a necessary condition to generate incomplete contracts. However, according to Kathry Spier, there is a particular type of asymmetrical information which can lead to contractual incompleteness: "Specifically, an individual may refrain from including a particular clause in a contract in order to signal his type." (1992, p. 432). For instance, an athlete's agent may advise her to refrain from asking for an injury clause, because the team manager would infer from such a request that the athlete is more accident prone and would make the terms of the contract worse. In our viewpoint, this type of asymmetrical information which is related to signalling one's identity can be better defined as an "Identification" problem. Thomas Schelling (1963) identified this problem in the context of strategic moves. An important characteristic of any game is how much each side knows about the other's value system; but a similar information problem arises with respect to sheer identification. The bank employee who would like to rob the bank if he could only find an outside collaborator and the bank robber who would like to rob the bank if only he could find an outside accomplice may find it difficult to collaborate because they are unable to identify each other, there being severe penalties in the event that either should declare his intentions to someone who proved not to have identical interests.

Furthermore, identification, like communication, is not necessarily reciprocal; and the act of self-identification may sometimes be reversible and sometimes not. One may achieve more identification than he bargained for, once he declares his interest in an object ${ }^{25}$ as Angelo's example shows. In this case, one's identity is not given. It is a variable depending on the strategic moves that one takes. Accordingly, self-identification depends on specific relationships among agents. But this means that one's identity is not just determined by one's individual characteristics but also by one's specific relationships with others. In this context, every individual has two different types of identity: intrinsic identity and extrinsic identity. The first one is specific to one's individual characteristics,

${ }^{25}$ Schelling cites a nice example from Shakespeare's Measure for Measure : "Angelo, acting in place of the Duke, has a prisoner whom he proposes to kill. He could torture him, but he has no incentive to. The victim has a sister, who arrives to plead for his life. Angelo, finding the sister attractive, proposes a dishonorable bargain; the sister submits. At this point the game has been expanded simply by the establishment of identity and of a line of communication. Angelo's only interest in torturing the brother is in what he may gain by making a threat to do so; once there is somebody available to whom the threat can profitably be communicated, the possibility of torture has value for Angelo-not the torture itself, but the threatening of it. The sister has gotten negative value out of her trip; having identified her interest and made herself available to receive the threatening message, she has been forced to suffer what she would not have had to suffer if she had never made her identity known or if she could have disappeared into the crowd before the threat was made." (1963, p. 140). 
while the second one is relationship specific or social. Every agent is, hence, to be considered as a social individual. Since intrinsic and extrinsic identities of the same agent can be different, every agent may admit multiple identities. The identification problem can lead to incomplete contracts, because in contrast to the general equilibrium theory or comprehensive optimal contracts, every agent can have multiple identities and the one adopted by the agent is relationship specific.

4) Bounded rationality: If the contractual parties are boundedly rational (see, Herbert Simon, 1959, 1962), they may be unable to anticipate every eventuality, and may find it too difficult to decide and reach agreement about how to deal with all the eventualities which they do foresee. Bounded rationality may also limit the types and complexity of revision games that the buyer and seller can conceive of. In this sense bounded rationality can be subdivided into three separate but related issues: 1) Unpredictability of all contingencies in a complex world; 2) Deciding and negotiating problems in case of unpredictable eventualities; 3) Different beliefs or representations of the world among agents and their learning process through mistakes. All aspects of bounded rationality can generate contractual incompleteness (see Hart and Holmstrom, 1987, p. 132; Spier, 1992, p. 432; Hart, 1995, p. 23, Tirole, 1994, pp. 44-45).

In Transaction Costs theory, bounded rationality is a semi strong form of rationality that can be interpreted as informational limitations of agents who are assumed to be intendedly rational (Williamson, 1985, pp. 45-47). Williamson adopts an intermediary position in the debate between Carnegie School and mainstream economics over maximizing behavior and rationality hypothesis during the seventies (Williamson, 1975, pp. 21-23). While accepting behavioral assumption of bounded rationality, he rejects Simonion's type of bounded rationality (used particulary by evolutionary theories like that of Nelson and Winter, 1982) as the weak form of rationality or "organic rationality" which deals with sheer ignorance and learning process (Williamson, 1985, pp. 46-47)26. Bounded rationality in Williamsonian sense means that it will be costly for agents to contemplate and contract for every contingency that might arise over the course of transaction. As David Kreps (1990, p. 744) justly remarks, it is useful to distinguish between eventualities that

26 Williamson (1985, pp. 44-47) distinguishes three levels of rationality: 1) Rationality in the strong form which contemplates maximizing; 2) Bounded Rationality as semi strong form of rationality which contemplates minimizing costs given the informational limitations; 3) Organic Rationality as the weak form of rationality which contemplates the "satisfycing" (Simon) conditions. The same classification is also adopted by Kreps (1990, p. 745): "For degree of rationality, our three categories are complete rationality, bounded rationality, and behavioral." 
are unpredictable and those that could be foreseen but that are not foreseen because of the costs of contemplation. However, from a theoretical point of view, these two categories could be combined by saying that the cost of foreseeing the first sort is infinite. Furthermore, bounded rationality implies that even if individual plans can be made, it is hard for the contracting parties to negotiate about these plans, not least because they have to find a common language to describe states of the world and actions with respect to which prior experience may not provide much of a guide.

While it is usually stressed that bounded rationality has hardly been formalized, Lipman (1993) suggests a method to formalize this concept and shows that incomplete contract, is in fact, bounded rationality. He defines limited rationality in terms of psychological costs of evaluating the consequences of the parties' actions and decisions.

5) Multi-stage bargaining and multilateral trading relationships: The literature on vertical integration has focused almost exclusively on bilateral trading relations, where a single supplier produces an input for use by a single buyer. However, in most settings, economies of scale and/or scope dictate that supply or purchasing relationships be multilateral, as when a manufacturer supplies inputs to a number of firms or a retailer handles numerous manufacturers' products. Bolton and Whinston (1993) try to extend the analysis of transaction costs/incomplete contracting models of vertical integration on the basis of bilateral trading relationships (most notably that of Grossman and Hart, 1986) to multilateral settings. Moreover, Busch and Horstmann (1992) investigate the contracting parties' strategic advantage from the specification of an incomplete contract in the first of a multistage contract bargaining procedure.

While transaction costs of various sorts are a crucial ingredient of the property rights approach, the identification problem as well as bounded rationality in the sense that agents have limited cognitive, computational or comprehension skills are not. In contrast, bounded rationality and identification problem are essential for the Transaction Costs theory in its explication of contractual incompleteness and institutional arrangements or governance structures.

In his survey on the incomplete contracts literature, Tirole (1994) concludes that this literature is in a methodological deadlock, since it cannot justify the incompleteness and cannot obtain different results from those achieved by the complete contracts literature 
either. Regarding the incompleteness, Tirole rejects the idea that ex post transaction costs (or the costs of verification by a third party) may be the cause of incompleteness. He argues that if there exists some information which is "observable but non verifiable", then the parties can always complete an incomplete contract by designing a revelation mechanism. However, as Moore (1992) notes Tirole's enforcement mechanism has two important limitations: first, it assumes benevolent judges; second, it requires a credible commitment by the parties (for example, a penalty clause in the contract) not to renegotiate the initial contract. In other words, we must adopt a paradoxical assumption that the parties are not sufficiently "sophisticated" to take advantage of ex post renegotiation whenever it would be mutually beneficial for them (Hart, 1995). In a recent contribution, Hart and Moore (1998) examine the irrelevance theorems of Maskin-Tirole and Tirole's (1994) criticism of incomplete contracting litterature. They notably underline that their conclusions rely heavily on the assumption that " parties to a contract are unable to commit not to renegotiate their contract...in contrast MaskinTirole take the point of view that, at least in an ideal world, commitment should be possible." (p. 3). Consequently, the renegotiation constraint justifies the "non verifiability" condition advocated by the incomplete contracts literature. There cannot be a revelation mechanism that may transform all observable information by the parties to a verifiable one by a third party.

\subsection{Bounded rationality of judge or agents}

According to the Transaction Costs theory, bounded rationality implies that all complex contracts are unavoidably incomplete and many are maladaptive. The reasons are two: many contingencies are unforeseen (and even unforeseeable); and the adaptations to those contingencies that have been recognized and for which adjustments have been agreed to are often mistaken. As Nelson and Winter (1982, pp. 96-136) justly explain these maladaptations are related to the learning process, since the parties acquire deeper knowledge of production and demand during contract execution than they possessed at the outset. The incompleteness of complex contracts has both practical and theoretical significance. The practical lesson is that all the relevant contracting action cannot be concentrated in the ex ante incentive alignement but some spills over into the ex post governance. The theoretical lesson is that differences among organization forms lose economic significance under a comprehensive contracting setup because any form of organization can then replicate any other (Hart, 1990). Transaction costs theory 
combines incompleteness with the farsighted contracting by describing the contracting process as one of "incomplete contracting in its entirety" (Williamson, 1996, pp. 9, 26, 46-47, 236). "Plausible farsightedness," as against hyper-rationality is considered to be a sufficient theoretical assumption.

For Williamson, the literature on incomplete contracting is a formalized version of some of the fundamental concepts of the transaction costs approach: “(...) the transaction cost approach to economic organization has progressively developed from its informal stages (1937) through performal and semiformal stages into fully formal analysis. The path-breaking paper by Sanford Grossman and Oliver Hart (1986), in which the incomplete contracting process was first modeled in a fully rigorous way, has been followed by a large and growing literature on incomplete contracting." (Williamson, 1996, pp. 372-73). These commonalities notwithstanding, there are also major differences. The most crucial difference between the transaction costs economics and Grossman-Hart-Moore (GHM) incomplete contract theory is that the former focuses on ex post haggling costs, whereas GHM ignores ex post maladaptation by their assumptions of common knowledge and costless ex post bargaining. The outcome is that all of the inefficiency in GHM is concentrated on the distorsions of ex ante investments in human assets (Williamson, 2000, p. 605, Whinston, 2001, p. 184) ${ }^{27}$. Regarding the behavioural assumption, the major difference between these two approaches are related to the meaning and place of bounded rationality.

In his article on the relationship between bounded rationality and institutions, Hart (1990) asks a central question: to what extent is bounded rationality an important ingredient of the property rights approach? He answers in this way: "I would argue that it is important only in quite limited sense-and, moreover, too much irrationality would undermine the story. What is crucial for the argument is that parties 1 and 2 cannot write an ex ante contract which specifies appropriate investment levels, or appropriate asset usage as a function of every possible contingency. One reason for this is that it may be hard for the parties to conceive of all the possible contingencies ex ante, or to think through all the aspects of a complex investment decision. This is indeed a form of bounded rationality. However, another possible explanation is that the parties can conceive of the various contingencies and dimensions of action, but cannot write them down in a clear enough way that an outside arbiter, such as a court, can verify them. (...) This does not seem so much a form of bounded rationality-rather a better description may be that the parties have bounded writing or communication skills.

${ }^{27}$ For a more detailed explanation of other differences between the transaction costs theory and the GHM theory, see Williamson, 2000, pp. 605-7, 609-10. 
To put it another way, it may be the courts' rather than the parties' rationality that is bounded." (Hart, 1990, pp. 698-99). Hart prefers not to treat ex ante transaction costs of writing a contract, since in that case bounded rationality of the contractual parties should be accounted for. This, of course, contradicts the perfect rationality postulate which justifies maximizing behavior. The alternative would be the treatment of ex post transaction costs, namely the non verifiability of contracts' terms by a third party (the court). In this case, the perfect rationality of agents would not be questioned, but judges must be considered as boundedly rational. However, the "bounded rationality" of judges is very paradoxal: on the one hand, judges are not sufficiently rational to observe all the parties' actions ("non verifiability" condition), on the other hand, they should be hyper rational and hyper informed in order to avoid any kind of ex post renegotiation.

In contrast to the mainstream economics of the seventies, the property rights approach acknowledges the importance of bounded rationality. However, in its explication of the incompleteness, it maintains the hyper-rationality assumption for the parties and only make some room for the judge's bounded rationality. This hyperrationality assumption excludes any unforeseen or unforeseeable events and, as Kirzner (1994) and Lachmann (1994), contend this assumption completely ignores sheer ignorance and hence the learning process as well as genuine novelty and the innovation. Furthermore, this assumption lacks some of the advantages of bounded rationality in treating the incompleteness. In a world of bounded rationality, parties should not be committed not to renegotiate their contract, since they will wish to preserve their option to revise their contract as unanticipated events occur. But, according to the hyper-rationality assumption, since the parties have unlimited ability to conceive of all the possible benefit/cost situations, any renegotiation can be anticipated and built into the revision process in the original contract. In reality, of course, parties frequently write a limited term contract, with the intention of renegotiating this when it comes to an end. In order to understand this phenomenon, bounded rationality is a more plausible assumption. The property rights theorists acknowledge this advantage (Hart and Moore, 1988, pp. 776-77; Hart, 1995, p. 81), but they repeatedly insist on the difficulties of formalizing bounded rationality (Hart and Holmstrom, 1987, p.148). Without denying these difficulties, it should be noted that some particular version of bounded rationality has already been formalized (see for example, Lipman, 1993, 1995; Rubinstein, 1998). Lack of agreement on the meaning and operational importance of bounded rationality is a key problem (Rubinstein, 1998, Kreps, 1999). However, the important 
point is the fact that the mathematical limitations are always invoked by the property rights approach to justify the neoclassical approach on "maximizing behavior" and the firm as a "standard form" contract (like the nexus of contracts approach) (see Hart, 1989, p. 1771). Williamson rightly notes that bounded rationality enters GrossmanHart-Moore's (GHM) version of incomplete contract theory in a very peculiar way: "Parties who are unable to write complete contracts ex ante are nevertheless able to anticipate ex ante what decisions will be taken ex post, contingent on state realizations...In effect, the GHM setup is one of selective unbounded rationality" (Williamson, 2000, p. 605).

As noted above the property rights approach admits the bounded rationality assumption for judges. But if the firm's hierarchy would be considered as a "private" court, why the same logic cannot be applied to the relationships inside the firm? In fact, this possibility has been explored by Williamson. "The efficacity of fiat turns critically on the fact that hierarchy is its own court of ultimate appeal" (Williamson O., 1992, p. 340). According to "classical" contractual approach, the firm is considered as a "nexus of treaties" (Williamson O., 1989, pp. 1-26). He suggests that the market contracts have to be distinguished from the intra-firm contracts. This distinction is justified according to the existence or the absence of confidence. The firm should necessarily establish confidence between its members, since in case of disputes, resorting to a legal authority will be costly in terms of efficiency. It is even sometimes impossible because of courts refusal to hear some intrafirm disputes over identical technical issues. It would be convenient to call for an internal arbitration in order to resolve such intrafirm disputes. Accordingly, hierarchy is its own court of ultimate appeal, and the court is not just outside the firm. This non contractible dimension of firm undermines the distinction between agents' bounded rationality and judges' bounded rationality 28 .

28 One of the referees argues that "First, incomplete contract theory does not fundamentally rely on bounded rationality (as Hart 1990 clearly argues). Second, the theory is with a high degree of probability flawed...My own instinct is that a much more radical break with the behavioral assumptions of mainstream game theoretic modeling strategy is required." In our opinion, the contractual incompleteness should clearly be founded on the bounded rationality assumption. However, in order to "formalize" this incompleteness, the bounded rationality assumption cannot be adopted for describing agents' behaviour. Since, there does not exist, "and probably will never exist, an axiomatic theory of bounded rationality." ( Furubotn and Richter, 1997, p. 239). Consequently, the theoretical strategy, as followed by Hart (1990, 1995), can be defined as one of admitting bounded rationality assumption for the judge (not for contracting parties), and a selective unbounded rationality assumption for the contracting agents. The strategy is sound in the sense that it remains loyal to its formalizing requirements while acknowledging the importance of bounded rationality assumption for establishing the "unverifiability" of incompete 


\subsection{Foundation of incomplete contracts}

The foundation of incomplete contracts is a major issue which has been addressed by several authors. The rich and interesting debate between Hart and Moore (1999), Maskin and Tirole (1999), and Segal (1999) has particularly shed light on this topic. Thus I will draw upon this discussion to clarify the foundation of contractual incompleteness.

The main goal of Maskin and Tirole's paper (1999) is to show that the incomplete contract theory (ICT) is in a deadlock and all incomplete contracts can be reduced to complete optimal contracts by devising a proper mechanism design. The authors claim that "This literature (ICT) usually assumes that contractual incompleteness is due to the transaction costs of describing- or of even foreseeing- the possible states of nature in advance. We argue, however, that such transaction costs need not interfere with optimal contracting (i.e. transaction costs need not be relevant), provided that agents can probabilistically forecast their possible future pay-offs.)" (1999, p. 83). In other words, Maskin and Tirole ( $\mathrm{M} \& \mathrm{~T}$ ) underline a tension between two different features of the literature: on the one hand, the theory assumes agents capable of performing dynamic programming, on the other hand, it postulates significant transaction costs leading to insufficient describability of states of nature. This tension can be resolved by accepting either "dynamic programming" procedure or the assumption of high transaction costs. In fact, the authors establish an irrelevance theorem which states that in case of commitment by agents not to renegotiate, the indescribability of states of nature does not impede optimal contracting if the optimal contract is "welfare-neutral" with regard to describable states. By "welfare-neutral", they allude to a situation where the equivalence of two different states regarding pay off implies the same utilities (the von Neumann-Morgenstern utilities) in both states (Maskin and Tirole, 1999, p. 84). Hence, the strength of "irrelevance theorem" may be resumed in its general applicability to implementation problems. M \& T demonstrate that, in the absence of renegotiation, it does not matter if actions are indescribable ex ante, provided that they can be described ex post. However, this major contribution to implementation theory does not undermine ICT for two reasons. First, this result heavily relies on the assumption that agents are

contracts. However, it falls short of what is required to found theoretically irreducible incompleteness. This flaw stems from the very nature of axiomatic theory: bounded rationality and axiomatic theory are allegedly not good bedfellows. My conjecture is that only an empirically based microeconomics (Simon, 1997) can really explore bounded rationality assumption. 
committed not to renegotaite, while in the presence of renegotiation, the describability of states does matter. Second, the "indescribability" of states is not an important assumption of ICT, while the "unverifiability" of states (and hence the need to renegotiate) is clearly an essential one.

Hart and Moore's paper (1999) discusses the first point ${ }^{29}$. They share with $\mathrm{M}$ and $\mathrm{T}$ (1999) that in the absence of renegotiation, the issue of whether or not actions can be described ex ante appears not to matter (Hart and Moore, 1999, pp. 124-126). Nevertheless, they show that non-describability is relevant when there is no commitment to renegotiate. Accordingly, the major issue in ICT is not the indescribability of states, but the assumption that parties to a contract are unable to commit not to renegotiate their contract. In fact, the ICT assumes that "both parties observe the state of nature at date $1 . .$. However the state is not verifiable, and nor are parties' final pay offs: that is, these things cannot be observed by outsiders, such as the courts. In the parlance of incomplete contract theory, the state and parties' pay offs are "observable, but not verifiable"." (op. cit., p. 118). In other words, although the ICT introduces the "indescribability" of all the states and hence adopts a selective unbounded rationality assumption for agents capable of dynamic optimizing, it does not rely mainly on this assumption. It mainly builds on another assumption: the bounded rationality of the judge as a non-contracting agent who cannot verify the terms of contract which are observable for contracting agents. This unverifiability condition is expressed in the assumption that agents are unable to commit not to renegotiate. There is a long and interesting discussion between Hart and Moore (1999) and Maskin and Tirole (1999) on the degree of commitment, and what comes out of this discussion is that there are cases which plead for the commitment and cases which do not. Of course, both parties acknowledge that renegotiation is important and pervasive in reality. However, the problem with renegotiation is that it cannot be easily reconciled with unbounded rationality assumption. Following the traditional view of renegotiation as a constraint on contracting, Segal

\footnotetext{
${ }^{29}$ Hart and Moore's model (1999) is inspired by Segal (1999) in which it is costless to describe ex ante the set of possible trades ("trades are describable"), and yet where the "null contract"- the quintessentially incomplete contract- is optimal. However Segal (1999) explicates contractual incompleteness on the basis of environmental complexity. This pertains to an inclusion to an inclusion of all possible transaction costs in explaining the incompleteness. Segal's Theorem 1 demonstrates that in a complex environment, the parties' inability to verify publicly observable information and their inability to prevent renegotiation impose severe constraints on contracting and may explain contractual incompleteness. However, the incompleteness is not only derived from this unverifiability problem. In fact, Theorem 2 shows that in a complex environment "the parties' inability to foresee all possible trades ex ante and the cost of describing them ex post impose additional constraints on contracting and extend the applicability of the incomplete contracting result." (Segal, 1999, p. 74).
} 
(1999) tries to justify the renegotiation on the basis of bounded rationality in the context of complex environments. Given the considerable cost of administrating complicated contractual message games ("formal commitment"), the parties may prefer not to write the renegotiation game directly in the ex ante contract, instead leaving the option of renegotiation ("informal commitment") open. The importance of complexity notwithstanding, a basic question can be raised: why may agents who are unboundedly rational choose to renegotiate? In fact, Maskin and Tirole (1999, p. 99) concede that "negotiation may be at odds with full rationality", and they claim that "a rational theory underlying renegotiation is still lacking". It is true that the renegotiation in Hart and Moore's theory (1999) does not derive from particular behavioural assumption about contracting agents (such as bounded rationality of agents), and in this sense ICT is not an adequate theory to explain the rationale for renegotiation. Nonetheless, ICT introduces the bounded rationality assumption for the court (non-contracting agent) and in this particular (although limited) sense, it provides a rationale for renegotiation.

\section{Conclusion}

The result of our study about different contractual theories (Agency theory, Property Rights theory and Transaction Costs theory) in relation to the general equilibrium theory is recapitualted in a table (see Annex). Compared to the Agency theory, the Property Rights approach has not only this advantage that it captures renegotiation, but it also accounts for the institutional identity of agents $^{30}$. While according to the Agency theory differences in organizational forms are irrelevant in obtaining efficient results given that optimal contracts be written on the basis of asymmetrical information and different incentive structure of the agents, the Property Rights theory tries to show the crucial role of organizational forms in generating efficiency. However, compared to the Property Rights approach, Transaction Costs economics has this advantage that it adopts the bounded rationality assumption which is more consistent with both kinds of transaction costs (ex ante and ex post) and with the analysis of institutions. The Incomplete contracts literature will find its logical coherence by revising its stand on the rationality postulate debate during the sixties and seventies. At last, Carnegie school's position fits better with incomplete contracts.

\footnotetext{
${ }^{30}$ In his recent survey on contractual choice, Masten $(1998$, p. 8) also notes that "Incomplete contract theory has permitted formal analysis of alternative organizational and institutional arrangements, especially the existence and locus of property rights ...for which the complete contract framework was unsuitable."
} 
We may also argue for the superiority of a temporary equilibrium framework rather than an intertemporal one, since boundedly rational individuals who are self-interested but without guile can be better described by a temporary equilibrium analysis (Kreps, 1990, p. 747). Furthermore, this assumptional revision will invoke some new and difficult questions, most notably on the relevance of a certain strand of contractarian vision of society and institutions. Borrowing Hausman and McPherson's (1993) distinction between two strands of "contractualism", namely the mutual advantage strand (exemplified by Hobbes and Hume) and the impartiality one (exemplified by Kant and Rousseau) ${ }^{31}$, we can ask whether incomplete contracts can be compatible with the former one? In an incomplete contractual setting, institutions are justified by the imperfections of contracts and defections of rationality postulate and maximizing behavior. Consequently, society cannot be regarded as the outcome of an optimal contract between individuals. Contrarily, society exists despite the pitfalls of contractual relationships among agents. This explains why in studying the genesis of society, we cannot rely on a general theory of individual choice, and why a general theory of collective action or coordinating mechanism would be relevant.

To sum up, we conclude that while asymmetrical information is required to pass from acontractual general equilibrium setting to complete optimal contracts, it is not a sufficient condition to make sense of institutional identity of agents. To understand the incompleteness of contracts, we do not necessarily need the asymmetrical information assumption. Incomplete contracts can be generated despite the symmetrical information assumption where the observability of all variables by the contractual parties cannot avoid the unverifiability of contract's terms by an exterior or a third party. While the complete contractual world is non-institutional, the incomplete contracts allow us to make sense of institutional identity of agents.

\footnotetext{
${ }^{31}$ According to Hausman and McPherson (1993, pp. 708-12), the first strand tends to identify rationality with self-interest and agreement with the outcome of bargaining, leading thus to a view of justice as mutual advantage. Whereas, the second one tends to identify rationality with the autonomous pursuits of ends and agreement with the outcome of a shared pursuit of common principles thus to a view of justice as impartiality.
} 


\begin{tabular}{|c|c|c|c|c|}
\hline \begin{tabular}{l|l} 
Theory \\
\end{tabular} & $\begin{array}{l}\text { Walrasian general } \\
\text { equilibrium theory (Arrow- } \\
\text { Debreu) }\end{array}$ & $\begin{array}{l}\text { Principal-Agent } \\
\text { theory }\end{array}$ & $\begin{array}{l}\text { Property rights theory } \\
\end{array}$ & Transaction costs theory \\
\hline Number of agents & Infinite (impersonal market) & Two & Three & $\begin{array}{l}\text { "Fundamental transformation" } \\
\text { - Numerous (impersonal } \\
\text { market) } \\
\text { c Two agents (bilateral } \\
\text { contracts, personal market) } \\
\dot{C}_{\text {One agent (unified, }} \\
\text { hierarchy) }\end{array}$ \\
\hline Rationality Postulate & Rationality & Rationality & $\begin{array}{l}\text { - Rationality of parties } \\
\text { to a contract } \\
\text { judges }\end{array}$ & Bounded rationality of agents \\
\hline Information structure & Symmetrical & Asymmetrical & $\begin{array}{l}\text { Symmetrical between } \\
\text { contractants } \\
\text { judge andmetrical between } \\
\text { (observabilitis and non } \\
\text { verifiability) }\end{array}$ & $\begin{array}{l}\text { Asymmetrical (transaction costs) } \\
\text { - Transaction costs } e x \\
\text { ante } \\
\text { post Transaction costs } e x \\
\text { pox }\end{array}$ \\
\hline Incentive structure & Absent & $\begin{array}{l}\text { Present } \\
\text { • Moral } \\
\text { hazard } \\
\bullet \quad \text { Adverse } \\
\text { selection }\end{array}$ & $\begin{array}{cl}\text { Present } & \text { Holdup } \\
\dot{0} & \text { Opportunism, credible } \\
\text { threat }\end{array}$ & $\begin{array}{cl}\text { Present } & \\
: & \text { Moral hazard } \\
: & \text { Adverse selection } \\
: & \text { Holdup } \\
\text { Opportunism, credible } \\
\text { threat }\end{array}$ \\
\hline $\begin{array}{l}\text { Maximizing (optimizing) } \\
\text { behaviour }\end{array}$ & Present & Present & Present & $\begin{array}{l}\text { Relaxed (minimizing the } \\
\text { transaction costs) }\end{array}$ \\
\hline Type of contract & $\begin{array}{l}\text { Acontractual } \\
\text { : Tâtonnement } \\
\text { Contracts", but not } \\
\text { bilateral ones }\end{array}$ & $\begin{array}{l}\text { Optimal Complete } \\
\text { contracts }\end{array}$ & Incomplete contracts & Incomplete contracts \\
\hline Organizational forms & $\begin{array}{l}\text { Absent (Modigliani-Miller } \\
\text { theorem) }\end{array}$ & $\begin{array}{l}\text { Absent (Modigliani- } \\
\text { Miller theorem) }\end{array}$ & $\begin{array}{cl}\text { Present } & \\
\bullet & \text { Vertical integration } \\
\bullet & \text { Lateral integration }\end{array}$ & $\begin{array}{ll}\text { Present } & \\
: & \text { Market } \\
\text { form) } & \text { Hierarchy (U form and M } \\
\text { : } & \text { Hybrid forms }\end{array}$ \\
\hline Role of institutions & $\begin{array}{l}\text { Ainstitutional } \\
\text { (Coase theorem) }\end{array}$ & $\begin{array}{l}\text { Ainstitutional } \\
\text { (Coase theorem) }\end{array}$ & $\begin{array}{l}\text { Institutional (property rights, } \\
\text { political power, customs, etc.) }\end{array}$ & $\begin{array}{l}\text { Institutional } \\
\cdot \text { Institutional } \\
\text { arrangements } \\
\cdot \text { Institutional } \\
\text { environment (property rights, } \\
\text { political power, etc.) } \\
\end{array}$ \\
\hline
\end{tabular}

Economie et Institutions $-\mathrm{n}^{\circ} 1-2^{\mathrm{e}}$ semestre 2002 


\section{Bibliography}

AGHION P., DEWATRIPONT M., and REY P. (1994), "Renegotiation Design with Unverifiable Information," Econometrica, vol. LXII, 25782.

AGHION P. and HERMALIN B. (1990), "Legal Restrictions on Private Contracts Can Enhance Efficiency," Journal of Law, Economics and Organizations, vol. VI, pp. 381-409.

ALLEN F. and GALE D. (1992), "Measurement Distorsion and Missing Contingencies in Optimal Contracts," Economic Theory, vol. II, pp. 1-26.

ANDERLINI L. and FELLI L. (1994), "Incomplete Written Contracts: Undescribable States of Nature," Quarterly Journal of Economics, vol. 109, pp. 1085-1124.

ARROW K. J. [1953] (1971), "The Role of Securities in the Optimal Allocation of Risk-Bearing", reprinted in Arrow K. J. , Essays in the Theory of Risk Bearing, Markam, Chicago.

ARROW K. J. (1959), "Toward a theory of price adjustment," in Abramowitz M. (ed.), The Allocation of Economic Resources, Stanford University Press, Stanford.

ARROW K. J. (1965), Aspects of the Theory of Risk Bearing, Yrjo Johansson Foundation, Helsinki.

ARROW K. J. (1985), "The Economics of Agency," in Pratt J. and Zeckhauser (eds.), Principals and Agents: The Structure of Business, Harvard Business School Press, Boston, pp. 37-51.

ARROW K. J. and Hahn F. H. (1971), General Competitive Analysis, Holden-Day, San Francisco.

AYERS I. and GERTNER R. (1992), "Strategic Contractual Inefficiency and the Optimal Choice of Legal Rules," Yale Law Journal, vol. 101, no. 4, pp. 729-73.

AZARIADIS C. (1993), Intertemporal Macroeconomics, Blackwell, Cambridge, Mass.

BARRO R. J. (1981), "The Equilibrium Approach to Business Cycles," in Barro R. J. (ed.), Money Expectations and Business Cycles, Academic Press, New York.

BARZEL Y. (1982), "Measurement Cost and the Organization of Markets," Journal of Law and Economics, vol. 25, pp. 27-48.

BARZEL Y. (1989), Economic Analysis of Property Rights, Cambridge University Press, Cambridge. 
BENASSY J. P. (1982), The Economics of Market Disequilibrium, Academic Press, New York.

BENASSY J. P. (1986), Macroeconomics: An Introduction to the NonWalrasian Approach, Academic Press, New York.

BERNHEIM B. D. and WHINSTON M. D. (1998), "Incomplete contracts and strategic ambiguity," The American Economic Review, vol. 88, no. 4, pp. 902-932.

BOLTON P. and WHINSTON M. (1993), "Incomplete Contracts, Vertical Integration, and Supply Assurance," Review of Economic Studies, vol. 60, pp. 121-148.

BUSCH L. A. and HORSTMANN I. (1992), "Endogenous Incomplete Contracts," Mimeo, University of Waterloo and University of Western Ontario.

BOYCKO M., SHLEIFER A. and VISHNY R. (1996), "A Theory of Privatisation," The Economic Journal, vol. 106, no. 435.

CALDWELL B. (1997), "Hayek and Socialism," Journal of Economic Literature, vol. XXXV, pp. 1556-1915.

CASS D. and SHELL K. (1983), "Do Sunspots Matter?" Journal of Political Economy, vol. 91, no. 2, pp. 193-227.

CHAIGNEAU N. (1997), "Contrat et utilité : origines et fondements de la théorie de l'échange de Francis Y. Edgeworth," Thèse pour le Doctorat en Science Economique, Université de Paris I-PanthéonSorbonne.

CHEUNG T. Y. (1991), "Incomplete Contracts, Specific Investments, and Risk Sharing," Review of Economic Studies, vol. 58, no. 5, pp. 1031-42.

COASE R. (1960), "The Problem of Social Cost," Journal of Law and Economics, vol. 3, pp. 1-44.

DAHLMAN. C. (1979), "The problem of externality," Journal of Law and Economics, vol. 22.

DAVIS L., NORTH D. (1971), Institutional change and American economic growth, Cambridge University Press, Cambridge.

DAY R. D. (1964), "Review of A Behavioral Theory of the Firm by Cyert and March," Econometrica, vol. 32, pp. 461-65.

DE ALESSI L. (1983), "Property Rights, Transaction Costs, and XEfficiency: An Essay in Economic Theory," The American Economic Review, vol. 73, no. 1, pp. 64-81.

DEBREU G. (1959), Theory of Value, Wiley, New York. 
DEMSETZ H. (1997), "The Firm in Economic Theory: A Quiet Revolution," The American Economic Review, vol. 87, no. 2, pp. 426430.

DEWATRIPONT M. (1989), "Renegotiation and Information Revelation over Time: The Case of Optimal Labor Contracts," Quarterly Journal of Economics, vol. 104, no. 3, pp. 589-619.

DONZELLI F. (1989), "The Concept of Equilibrium in Neoclassical Economic Theory. An Enquiry into the Evolution of General Competitive Analysis from Walras to the "Neo-Walrasian Research Programme," Ph.D. Dissertation, University of Cambridge.

DYE R.A. (1985), "Costly Contracts Contingencies," International Economic Review, vol. XXVI, pp. 233-50.

EDGEWORTH F. Y. [1881] (1967), Mathematical Psychics: An Essay on the Application of Mathematics to the Moral Sciences, Kegan and Paul \& Co. , London, reprinted A. M. Kelly, New York.

EDLIN A. and REICHELSTEIN S. (1996), "Holdups, Standard Breach Remedies, and Optimal Investment," The American Economic Review, vol. 86, no. 3, pp. 478-501.

EVANS G. and HONKAPOHJA S. (1992), "Adaptive Learning and Expectational Stability: An Introduction," Mimeo, London School of Economics.

FURUBOTN E. and RICHTER R. (1997), Institutions and Economic Theory, The Contribution of the New Institutional Economics, The University of Michigan Press, Ann Arbor.

GARVEY G. (1991), "Encouraging Specific Investments in a One Shot and Repeated Partnership: Some Comparisons," Mimeo, Australian Graduate School of Management.

GOLDBERG V. and ERICKSON J. (1982), "Long-Term Contracts for Petroleum Coke," Department of Economics Working Paper Series No. 206, University of California-Davis.

GRANDMONT J. M. (ed.) (1987), Temporary Equilibrium: Selected Readings, Academic Press, New York.

GREEN J. R. (1973), "Temporary General Equilibrium in a Sequential Trading Model with Spot and Future Transactions," Econometrica, vol. 41, pp. 1103-23.

GROSSMAN S. (1977), "The Existence of Futures Markets, Noisy Rational Expectations and Informational Externalities," Review of Economic Studies, vol. 64, no. 3, pp. 431-49. 
GROSSMAN S. (1981), "An Introduction to the Theory of Rational Expectations under Asymmetrical Information," Review of Economic Studies, vol. 68, pp. 541-59.

GROSSMAN S. (1989), The Informational Role of Prices, The MIT Press, Cambridge, Mass.

GROSSMAN S. and HART O. (1980), "Takeover Bids, the Free-Rider Problem, and the Theory of the Corporation," Bell Journal of Economics, vol. 11, pp. 42-64.

GROSSMAN S. and HART O. (1986), "The Costs and Benfits of Ownership: A Theory of Vertical and Lateral Integration," Journal of Political Economy, vol. 94, no. 4, pp. 691-719.

GROUT P. (1984), "Investment and Wages in the Absence of Binding Contracts: A Nash Bargaining Approach," Econometrica, vol. 52, no. 2, pp. 449-60.

GUESNERIE R. and WOODFORD M. (1991), "Endogenous Fluctuations," Mimeo, DELTA.

HAHN F. (1968), "On Warranted Growth Paths," Review of Economic Studies, vol. 35, pp. 175-84.

HALONEN M. (1994), "Reputation and Allocation of Ownership," Mimeo, Helsinki School of Economics.

HART O. (1988), "Incomplete Contracts and the Theory of the Firm," Journal of Law, Economics, and Organization, vol. IV, no. 1, pp. 119139.

HART O. (1989), "An Economist's Perspective on the Theory of the Firm," Columbia Law Review, vol. 89, pp. 1749-1757.

HART O. (1990), "Is "Bounded Rationality" an Important Element of a Theory of Institutions?", Journal of Institutional and Theoretical Economics, vol. 146, pp. 696-702.

HART O. (1995), Firms, Contracts, and Financial Structure, Clarendon Press, Oxford.

HART O. (2001), "Financial Contracting," Journal of Economic Literature, vol. XXXIX, no. 4, pp. 1079-1100.

HART O. and Holmstrom B. (1987), "The Theory of Contracts," in Bewley T.F. (ed.), Advances in Economic Theory, Cambridge University Press, Cambridge, pp. 71-155.

HART O. and Moore J. (1988), "Incomplete Contracts and Renegotiation," Econometrica, vol. 56, no. 4, pp. 755-785. 
HART O. and Moore J. (1990), "Property Rights and the Nature of the Firm," Journal of Political Economy, vol. 98, pp. 1119-58.

HART O. and Moore J. (1999), "Foundations of Incomplete Contracts", The Review of Economic Studies, vol. 66, 1999, pp. 115138.

HASHIMOTO M. (1981), "Firm-Specific Human Capital as a Shared Investment," The American Economic Review, vol. 71, no. 3, pp. 475482.

HAUSMAN D. M. and MCPHERSON M. S. (1993), "Taking Ethics Seriously: Economics and Contemporary Moral Philosophy," Journal of Economic Literature, vol. XXXI, pp. 671-731.

HAYEK F. [1937] (1948), "Economics and Knowledge," reprinted in Hayek F. (ed.), Individualism and Economic Order, University of Chicago Press, Chicago, pp. 33-56.

HAYEK F. [1945] (1948), "The Use of Knowledge in Society", reprinted in Hayek F. (ed.), 1948, pp. 71-91.

HAYEK F. [1946] (1948), "The Meaning of Competition," reprinted in Hayek F. (ed.), 1948, pp. 92-106.

HAYEK F. [1968] (1978), "Competition as a Discovery Procedure," in Hayek F. (ed.), New Studies in Philosophy, Politics, Economics and the History of Ideas, University of Chicago Press, Chicago, pp. 179 -90.

HERMALIN B. (1988), "Adverse Selection and Contract Length," in Three Essays on the Theory of Contracts, Massachusetts Institute of Technology, Ph.D. thesis.

HICKS J. (1939), Value and Capital, Clarendon, Oxford.

HOLMSTROM B. and Tirole J. (1989), "The Theory of Firm," in Schmalensee R. and Willig R.D. (eds.), Handbook of Industrial Organization, vol. 1, Handbook in Economics, no. 10, North-Holland, Amsterdam, pp. 61-133.

HURWICZ L. (1973), "The Design of Mechanisms for Resource Allocation," The American Economic Review, vol. 63, pp. 1-30.

JENSEN M. (1986), "Agency costs and free cash flow, corporate finance and takeovers," The American Economic Review, Papers and proceedings, vol. 76, pp. 323-29.

JENSEN M. and Meckling W. (1976), "Theory of the Firm: Managerial Behavior, Agency Costs, and Capital Structure," Journal of Financial Economics, vol. 3, pp. 305-60. 
JOSKOW P.A. (1985), "Vertical Integration and Long Term Contracts: The Case of Coal-Burning Electric Generating Plants," Journal of Law, Economics and Organization, vol. 1, no. 1, pp. 33-80.

KIRZNER I. (1994), "On the economics of time and ignorance," in Boettke P. and Prychitko D. (1994), The Market Process, Essays in Contemporary Austrian Economics, Edward Elgar, Hants.

KLEIN B., CRAWFORD R.and ALCHIAN A. (1978), "Vertical integration, appropriate rents, and the competitive contracting process", Journal of Law and Economics, vol. 21.

KREPS D. (1990), A Course in Microeconomic Theory, Princeton University Press, Princeton.

KREPS D. (1999), "Markets and Hierarchies and (Mathematical) Economic Theory," in G. Carroll and Teece D. (eds.), Firms, Markets, and Hierarchies, Oxford University Press, N.Y., pp. 121-55.

LACHMANN L. (1994), "On the economics of time and ignorance," in Boettke P. and Prychitko D. (1994), The Market Process, Essays in Contemporary Austrian Economics, Edward Elgar, Hants.

LEIBENSTEIN H. (1966), "Allocative Efficiency vs. 'X-Efficiency'," The American Economic Review, vol. 56, pp. 392-415.

LIPMAN B. (1993), "Limited Rationality and Endogenously Incomplete Contracts," Mimeo, Queen's University.

LIPMAN B. (1995), "Information Processing and Bounded Rationality: A Survey," Canadian Journal of Economics, vol. 28, pp. 42-67.

LUCAS R. E. (1972), "Expectations and the Neutrality of Money," Journal of Economic Theory, vol. 4, pp. 103-124.

LUCAS R. E. (1980), "Methods and Problems in Business Cycle Theory," Journal of Money, Credit and Banking, vol. 12, pp. 696-715.

MACLEOD W.B. (1996), "Decision, Contract, and Emotion: Some Economics for a Complex and Confusing World," Canadian Journal of Economics, vol. 29, no. 4, pp. 788-810.

MALCOMSON J. (1997), "Contracts, Hold-Up, and Labor Markets," Journal of Economic Literature, vol. XXXV, pp. 1916-1957.

MASKIN E. and TIROLE J. (1999), "Unforeseen Contingencies and Incomplete Contracts," The Review of Economic Studies, vol. 66, pp. 83-114.

MASTEN S.C. (1998), "Contractual Choice," in Boukaert B. and De Geest G. (ed.) Encyclopedia of Law \& Economics, Edward Elgar Publishing and the University of Ghent (forthcoming). 
MODIGLIANI F. and MILLER M. (1958), "The Cost of Capital, Corporation Finance, and the Theory of Investment," The American Economic Review, vol. 48, pp. 261-97.

MUKERJI S. (1998), "Ambiguity Aversion and Incompleteness of Contractual Form," The American Economic Review, vol. 88, no. 5, pp. 1207-1232.

NÖLDKE G. and Schmidt K. (1995), "Option Contracts and Renegotiation," Rand Journal of Economics, vol. 26, no. 2, pp. 16379 .

NEGISHI T. (1972), General Equilibrium Theory and International Theory, North-Holland, Amsterdam.

NEGISHI T. (1989), "Tâtonnement and Recontracting," in Eatwell J., Milgate M. and Newman P. (eds.), The New Palgrave, General Equilibrium, Norton, London, pp. 281-296.

NELSON R. and WINTER S. (1982), An Evolutionary Theory of Economic Change, The Belknap Press of Harvard University Press, Cambridge, Massachusetts.

NORTH N. (1981), Structure and Change in Economic History, Norton, New York.

NORTH N. (1984), "Government and the Cost of Exchange," Journal of Economic History, vol. 44, pp. 255-264.

NORTH N. (1990), Institutions, Institutional Change and Economic Performance, Cambridge University Press, Cambridge.

NORTH N. (1993), "Institutions and Credible Commitment," Journal of Institutional and Theoretical Economics, vol. 149, no. 1, pp. 11-23.

POLANYI M. (1967), The Tacit Dimension, Routledge and Kegan Paul, London.

RADNER R. (1980), "Equilibrium under Uncertainty," in Arrow K. J. and Intriligator M. D. (eds.), Handbook of Mathematical Economics, chapter 20, vol. II, North-Holland, Amsterdam, pp. 33-52.

ROGERSON W. (1984), "Efficient Reliance and Damage Measure for Breach of Contract," Rand Journal of Economics, vol. 15, no. 1, pp. 39-53.

ROGERSON W. (1992), "Contractual Solutions to the Hold-Up Problem," Review of Economic Studies, vol. 59, no. 4, pp. 777-93.

ROSEN S. (1985), "Implicit Contracts: A Survey," Journal of Economic Literature, vol. 23, no. 3, pp. 1144-75. 
RUBINSTEIN A. (1998), Modeling Bounded Rationality, The MIT Press, Cambridge, Mass.

SAPPINGTON D. E. M. (1991), "Incentives in Principal-Agent Relationships," Journal of Economic Perspectives, vol. 5, no. 2, pp. 45-66.

SCHELLING T. (1963), The Strategy of Conflict, A Galaxy Book, Oxford University Press, New York.

SCITOVSKY T. (1943), "A Note on Profit Maximization and its Implications," Review of Economic Studies, no. 1, vol. 11, pp. 57-60.

SEGAL I. (1999), "Complexity and Renegotiation: A Foundation for Incomplete Contracts," The Review of Economic Studies, vol. 66, pp. 57-82.

SHAVELL S. (1980), "Damage Measures for Breach of Contract," Bell Journal of Economics, vol. 11, pp. 466-90.

SHELL K. (1989), "Sunspot Equilibrium", in Eatwell J., Milgate M. and Newman P. (eds.), The New Palgrave, General Equilibrium, Norton, London, pp. 274-280.

SHILLER R. (1978), "Rational Expectations and the Dynamic Structure of Macroeconomic Models: A Critical Review," Journal of Monetary Economics, vol. 4, pp. 1-44.

SIMON H. A. (1951), "A Formal Theory of the Employment Relationship," Econometrica, vol. 19, pp. 293-305.

SIMON H. A. (1959), "Theories of Decision Making in Economics and Behavioral Science," The American Economic Review, vol. 49, pp. 253-83.

SIMON H. A. (1962), "New Developments in the Theory of the Firm," The American Economic Review, Papers and Proceedings, vol. 52, pp. $1-15$.

SIMON H. (1997), An Empirically Based Microeconomics, Cambridge, UK, Cambridge University Press.

SPEAR S. (1985), "Rational Expectations in the Overlapping Generations Model," Journal of Economic Theory, vol. 35, pp. 251275.

SPENCE M. (1977), "Consumer Misperceptions, Product Failure, and Producer Liability," Review of Economic Studies, vol. 44.

SPIER K. (1992), "Incomplete Contracts and Signalling," Rand Journal of Economics, vol. 23, pp. 432-43. 
TIROLE J. (1986), "Procurement and Renegotiation," Journal of Political Economy, vol. 94, no. 2, pp. 235-59.

TIROLE J. (1988), The Theory of Industrial Organization, MIT Press, Mass., Cambridge.

TIROLE J. (1994), "Incomplete Contracts: Where do we stand?" , Walras-Bowley lecture, delivered at the North American Summer Meetings of the Econometric Society, Quebec City, Mimeo, IDEI, 53 pages, publié dans Econometrica, vol. 67, no. 4, 1999, pp. 741-781.

VAHABI M. (1995), "The Austro-Hungarian Convergence through the Writings of J. Kornai”, Economie Appliquée, vol. XLVIII, no. 2, pp. 77103.

VAHABI M. (1997), "A Critical Survey of K.J. Arrow's Theory of Knowledge”, Cahiers d'économie politique, no. 29, pp. 35-65.

VAHABI M. (1998), "The Relevance of the Marshallian Concept of Normality in Interior and in Inertial Dynamics as Revisited by G. Shackle and J. Kornai", The Cambridge Journal of Economics, vol. 22, no 5, pp. 547-572.

WALKER D. A. (1973), "Edgeworth's theory of recontract," Economic Journal, vol. 83, pp. 138-149.

WALRAS L. [1874] (1954), Eléments d'économie politique pure ou théorie de la richesse sociale, trans. by Jaffé W. as Elements of Pure Economics, George Allen and Unwin, London.

WEITZMAN M. (1981), "Toward a Theory of Contract Types," Mimeo, MIT.

WHINSTON M. (2001), "Assessing the Property Rights and Transaction-Cost Theories of Firm Scope," American Economic Review, Papers and Proceedings, vol. 91, no. 2, pp. 184-188.

WILLIAMSON O. (1975), Market and hierarchies: analysis and antitrust implications, Free Press, New-York.

WILLIAMSON O. (1985), The Economic Institutions of Capitalism. Firms, Markets, Relational Contracting, The Free Press, New-York.

WILLIAMSON O. (1988), "Corporate finance and corporate governance," Journal of Finance, vol. 43, pp. 576-91.

WILLIAMSON O. (1989), "The firm as a nexus of treaties: An Introduction" , in Aoki M, Gustafsson B., and Williamson O. (eds.), The firm as a nexus of treaties, SCASS, Sage Publications, London.

WILLIAMSON O. (1992), "Markets, hierarchies, and the modern corporation. An unfolding perspective," Journal of Economic Behavior and Organization, vol. 17. 
WILLIAMSON O. (1996), The Mechanisms of Governance, Oxford University Press, Oxford.

WILLIAMSON O. (2000), "The New Institutional Economics: Taking Stock, Looking Ahead," Journal of Economic Literature, vol. XXXVIII, pp. 595-613. 